\title{
Skeletal muscle glycogenosis : an investigation of two dissimilar cases ${ }^{1}$
}

\author{
WILLIAM H. S. THOMSON, ${ }^{2}$ JOHN C. MACLAURIN, AND \\ JOHN W. PRINEAS \\ From the Department of Clinical Biochemistry, Glasgow Western Infirmary, \\ the Department of Child Health, University of Glasgow, and Glasgow Royal Infirmary
}

Glycogen is found in almost every tissue in the body, but is especially abundant in the liver where the content is very variable, and in skeletal muscle where the content is relatively constant except during prolonged exertion. The regulation of glycogen metabolism in these tissues is a matter of delicate equilibrium between a number of enzyme systems, defects in which may cause profound alterations in the amount and structure of the glycogen. The clinical results of such alterations have been known for many years as diseases of glycogen storage, or better, as the glycogenoses. The first cases, affecting liver and kidneys, were recognized by von Gierke in 1929. Since then other types of glycogenosis have been described and elucidated, including some which involve skeletal muscle.

This study deals with the clinical, histological, and biochemical identification of two dissimilar cases of skeletal muscle glycogenosis. One, in a 48-year-old man, is the fourth of its type to be formally elucidated; the other, in a 4-year-old boy, is the second case reported and the first to be fully described.

\section{CASE REPORTS}

CASE 1 (G.R.) A 48-year-old Scotsman was admitted to Glasgow Royal Infirmary for investigation of cramping retrosternal pain increasing over the last four years and beginning to radiate down his left arm. The pain was provoked by exertion and relieved by rest, but had not required Trinitrin; he had occasional palpitations but no dyspnoea or ankle oedema. He had smoked 40 cigarettes a day for 30 years.

Besides the ordinary childhood illnesses his history revealed a life-long tendency to remarkably rapid fatigue of the entire skeletal musculature, though after rest his physical strength was normal. No family history of a

${ }^{1}$ This work was supported by a grant of apparatus from the Muscular Dystrophy Group of Great Britain, and a preliminary report has appeared in the Proceedings of the Association of Clinical Biochemists $(1962,2,43)$.

${ }^{2}$ Present address: Muscle Research Laboratory, Knightswood Hospital, Glasgow, W.3. similar muscular condition, nor of consanguinity, coulक be found. The patient's only sibling, a brother, had dieds eight years previously of paralysis agitans after encepha $\overrightarrow{0}$ litis lethargica at the age of 7 years. The patient had fourhealthy, active children, a son aged 9 years and three daughters aged 15,11 , and 4 years.

Minimal exertion, such as slow walking on level ground could be sustained indefinitely. On vigorous exertion however, weakness invariably appeared within minutesึ in the muscles used, increasing rapidly on perseveranceto actual pain, tenderness, and prolonged loss of powerim proportion to the amount of exertion. Thus, rapid walk ing or climbing stairs quickly affected the thighs, cales,? and pelvic muscles, and manual work the muscles of arms and shoulder girdle. At no time did he recall haviog passed dark urine after such an episode. Though immeğio ate rest for a few minutes at the start of an attack pexe vented pain and restored full power, he sometimes foung that resolute persistence in reduced exertion suddem removed the discomfort and weakness, so that he contor then continue indefinitely at full power like a normal $f$ individual. This 'second wind' phenomenon was a rare occurrence, requiring great determination, and if hes paused at all the whole process had to be repeated.

On examination the patient was found to be an intellia gent middle-aged man of average height and weight, with no clinically detectable abnormality of any system? Electrocardiography showed only slight ST segmen $\overrightarrow{\vec{b}}$ depression in leads II, III, and AVF, minimal changes 3 consistent with early posterior myocardial ischaemia otherwise the cardiovascular system was entirely normalo In particular, the central and peripheral nervous systems showed no abnormality whatever. Muscle tone and powe were normal everywhere, with no sign of wasting of hypertrophy, but the moderate exertion of climbing two flights of stairs produced the symptoms just described? Spectroscopic examination of the urine after exerciseo showed no evidence of myoglobin. Intravenous edro phonium chloride (Tensilon) did not improve his exerciseo capacity, thus excluding a diagnosis of myasthenia gravis. Electromyography of the right quadriceps ando anterior tibial muscles on two occasions gave norma $\mathrm{F}$ records at rest and after exercise, and on voluntary con N traction and tetanic stimulation. With both arms im= mersed in hot water, normal and bilaterally equal refiex vasodilatation in both lower limbs was proved by a $13^{\circ} \mathrm{F}_{\mathrm{\omega}}^{\mathrm{N}}$ 
rise in temperature indicated by thermocouples on the pads of the great toes.

A routine blood examination showed $\mathrm{Hb} 14.5 \mathrm{~g} . \%$; red cell count 4.72 million/c.mm.; white cell count $6,400 /$ c.mm. with a normal differential count; E.S.R. $12 \mathrm{~mm}$. in the first hour. Serum sodium was $143 \mathrm{mEq}$./l., potassium 4.3 mEq./l., chloride $103 \mathrm{mEq} . / 1 ., \mathrm{CO}_{2}$ $27.2 \mathrm{mM}$./1., urea $32 \mathrm{mg}$. $/ 100 \mathrm{ml}$., and cholesterol $350 \mathrm{mg} . / 100 \mathrm{ml}$. Liver function tests were normal, with total serum proteins $6.6 \mathrm{~g}$. $/ 100 \mathrm{ml}$. (albumin $4 \cdot 0$, globulin 2.6); thymol turbidity 0.6 Maclagan units; serum alkaline phosphatase $9 \cdot 2$ King-Armstrong units $/ 100 \mathrm{ml}$.; serum bilirubin $0.4 \mathrm{mg}$. $/ 100 \mathrm{ml}$.

A routine urine examination showed no albumin, reducing substances, bile pigments, or myoglobin; normal microscopy, 24-hour output of creatine was nil, of creatinine $1.7 \mathrm{~g}$., of 17 -ketosteroids $8.7 \mathrm{mg}$., and of total 17 -hydroxycorticosteroids $9 \cdot 7 \mathrm{mg}$.

Special biochemical investigations were then carried out. These included a glucose tolerance test, the result of which was normal; and an adrenalin tolerance test after subcutaneous injection of $0.5 \mathrm{mg}$. adrenalin (Table I).

\section{TABLE I}

\section{ADRENALIN TOLERANCE TESTS}

Minutes after Injection

Blood Glucose (mg. per $100 \mathrm{ml}$ )

Adult G.R.

(Case 1)

Child J.W.

(Case 2)

\begin{tabular}{rrr}
\hline 0 & 72 & 76 \\
15 & 81 & 110 \\
30 & 101 & 105 \\
45 & 102 & 88 \\
60 & 95 & \\
90 & 88 &
\end{tabular}

Serum enzyme assays (Table II) were also carried out for aldolase by using coupled DPNH-dependent enzyme systems (Beisenherz et al., 1953; Slater, 1953); ${ }^{1}$ for SGOT and SGPT by the colorimetric method (Reitman and Frankel, 1957) ${ }^{2}$; and for creatine phosphokinase by the constant-pH titrimetric method (Cho, Haslett, and Jenden, 1960).

Blood lactic acid produced by exercise during ischaemia was studied both in the patient and in a healthy 19-yearold youth. Both subjects were rested in bed for 30 minutes. A sphygmomanometer cuff was inflated to $200 \mathrm{~mm}$. round one wrist to prevent arterial mixing, and an initial blood specimen taken from the antecubital vein by a hypodermic needle thereafter left indwelling and slowly

'Standardized reagents were supplied by C. F. Boehringer of Mannheim (British agents: Courtin and Warner, Ltd., Lewes, Sussex).

2Standardized reagents were supplied by the Sigma Chemical Co., St. Louis, U.S.A. (British agents: G. T. Gurr, London).

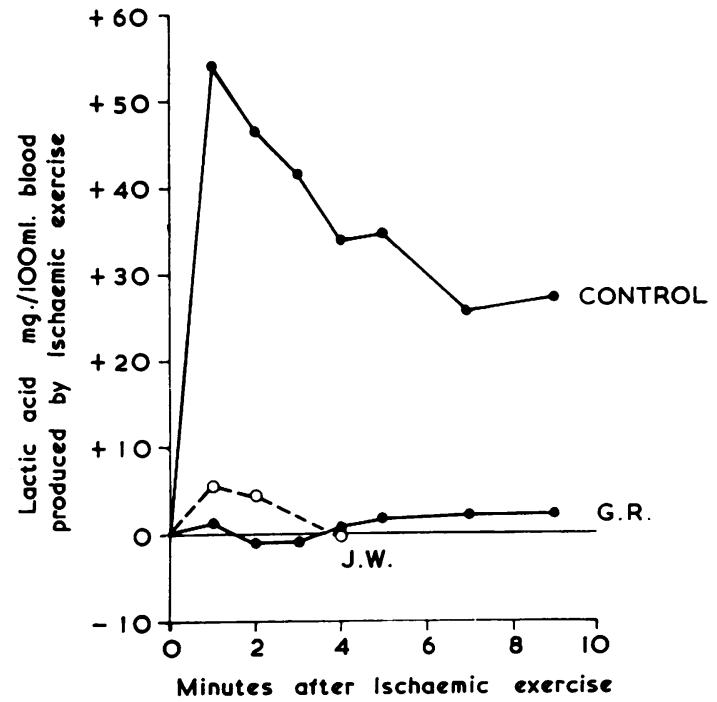

FIG. 1. Changes in blood lactic acid concentration after ischaemic exercise.

dripping to avoid clotting. An additional sphygmomanometer cuff was then inflated to $200 \mathrm{~mm}$. round the upper arm. The subject then vigorously exercised the forearm by squeezing the bulb to another sphygmomanometer for 45 seconds. At the end of this period the patient, but not the normal subject, began to experience severe cramp. One minute after terminating the exercise the upper arm cuff was deflated, the wrist cuff being kept at $200 \mathrm{~mm}$., and successive blood specimens were taken thereafter for nine minutes. Each specimen measured $2 \mathrm{ml}$., and was immediately discharged into a stoppered tube containing $2 \mathrm{ml}$. of $10 \%$ trichloracetic acid, shaken, and centrifuged. The lactic acid content of each clear aqueous supernatant was estimated by an elegant micro-diffusion procedure using Conway units (Ryan, 1958). The results are illustrated in Figure 1.

Studies in vitro were also carried out on a biopsy specimen of the patient's left gastrocnemius taken under general anaesthesia, placed in a chilled stoppered flask and processed immediately. The histological appearances are shown in Fig. 5 (PAS). The glycogen content (Table III), together with that of two specimens of muscle from normal individuals, was determined by the method of Good, Kramer, and Somogyi (1933). Anaerobic glycolysis of various substrates by a homogenate of the biopsy specimen was compared with that of normal muscle by

TABLE II

SERUM ENZYME ASSAYS

Adult G.R.

Aldolase (Bruns units $/ \mathrm{ml}$.)

Glutamic-oxalacetic transaminase (SGOT) (Sigma-Frankel units/ml.)

Glutamic-pyruvic transaminase (SGPT) (Sigma-Frankel units/ml.)

Creatine phosphokinase $(\mu \mathrm{M} / \mathrm{ml} . / \mathrm{min}$.)

\begin{tabular}{lcc} 
& Child J.W. & Normal Ranges \\
\hline $42 \cdot 6$ & $18 \cdot 4$ & $2 \cdot 3-8 \cdot 8$ \\
55 & 107 & $12-36$ \\
25 & 36 & $4-24$ \\
0.32 & $0 \cdot 38$ & $0.01-0 \cdot 10$
\end{tabular}


TABLE III

MUSCLE GLYCOGEN IN NORMAL AND TWO PATIENTS

Muscle Glycogen Content ( $\%$ Wet Weight)

\begin{tabular}{|c|c|c|}
\hline Normal Muscle & Adult G.R. (Case I) & Child J.W. (Case 2) \\
\hline $\begin{array}{l}1.5 \text { (vastus lateralis of } 12 \text {-year-old boy) } \\
1.6 \text { (flexor carpi ulnaris of } 60 \text {-year-old man) }\end{array}$ & 4·1 (L. gastrocnemius) & $\begin{array}{l}3.7 \text { (L. pectoralis major) } \\
7 \cdot 0 \text { (L. soleus) } \\
11.3 \text { (L. gastrocnemius) }\end{array}$ \\
\hline
\end{tabular}

TABLE IV

ANAEROBIC GLYCOLYSIS BY MUSCLE HOMOGENATES Substrate $\mu M$ Lactic Acid Formed per Gram Muscle (wet weight)

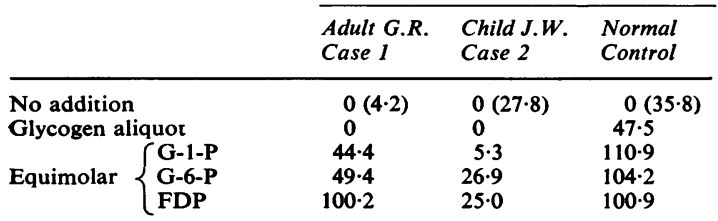

G-1-P = glucose-1-phosphate; G-6-P = glucose-6-phosphate; FDP = fructose-1,6-diphosphate

All incubations were for $30 \mathrm{~min}$. at $38^{\circ} \mathrm{C}$. using identical substrate quantities.

the methods of Schmid and Mahler (1959), lactic acid production being again determined by the method of Ryan (1958); the results are given in Table IV. Phosphorylase activity, together with that of two specimens of normal muscle, was determined by the method of Sutherland and Wosilait (1956) using G-1-P ${ }^{1}$ substrate in the presence of sodium fluoride, adenylic acid, and glycogen starter; the inorganic phosphate produced was estimated by the method of Gomorri (1942) and the results are illustrated in Fig. 2. Structural analysis (Dr. D. J. Manners, University of Edinburgh) of glycogen isolated from the biopsy specimen showed it to have a normal degree of branching, and to be quite different from phosphorylase limit dextrin or amylopectin; details of this analysis have been published elsewhere (Kjølberg and Manners, 1962).

${ }^{1}$ Glucose-1-phosphate.

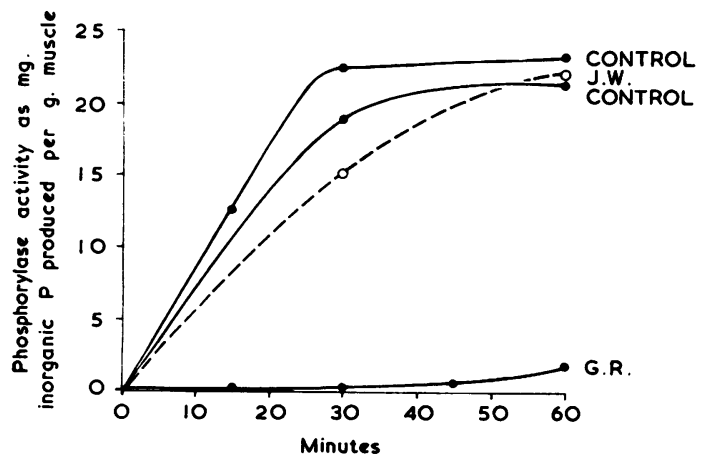

FIG. 2. Phosphorylase activity in homogenates of muscle biopsy specimens.
CASE 2 (J.w.) A 4-year-old boy, the younger child of healthy parents, was admitted to the Royal Hospital for Sick Children, Glasgow, for investigation of an abnorma gait. In early infancy several episodes of supraventriculare tachycardia had occurred, and at least two of these hado required digoxin therapy. Subsequently he developedes normally until the age of $2 \frac{1}{2}$ years, when increasingly heop began to walk on his toes and soon it became clear tha? he could walk in no other way. He did so very nimbly, however, was as active as other children, grew tired nosooner, and did not complain of muscular pain. The colour of his urine had always appeared normal. TherE had never been evidence to suggest palatal palsy.

On examination the patient was found to be a lively healthy-looking little boy who was $103 \%$ of expected weight and $105 \%$ of expected height. A $1: 5,000$ tuber N culin skin test was negative after 48 hours. Cardiovascularexamination showed a regular pulse rate of $74 / \mathrm{min}$. blood pressure of $100 / 70 \mathrm{~mm}$. $\mathrm{Hg}$; a short, innoce्d systolic murmur at all areas; no cardiac enlargements normal chest radiogram; and an electrocardiogra indicating only slight sinus arrhythmia. Likewise, clinically detectable abnormality could be found in theo central or peripheral nervous systems, nor in any otger system, with the notable exception of the skeleata musculature. In general, the body musculature, thouris of normal consistency and tone, seemed everywher slightly weaker and less well developed than usual for his age. In particular, both gastrocnemii were uncommonly bulky and uniformly firm, but not tender, and showed marked shortening which tautened the Achilles tendons causing an equal plantar-flexion deformity of both ankles resistant to passive reduction. Further voluntary? plantar flexion could be performed, but only feebly? Electromyography of both quadriceps and gastrocnemi $\overrightarrow{\vec{b}}$ showed a myopathic pattern on voluntary contraction 3 against resistance, with polyphasic low-voltage potentialsof short duration instead of the normal full interference pattern. No spontaneous action potentials were seen, and motor conduction times were normal. Spectroscopic examination of the urine after exercise showed no evidence of myoglobin.

A routine blood examination showed $\mathrm{Hb} 11.2 \mathrm{~g}$. \% red cell count 4.8 million/c.mm. (reticulocytes less than $1 \%$; white cell count $8,000 /$ c.mm.; E.S.R. $20 \mathrm{~mm}$. in the first hour. Blood urea was $29 \mathrm{mg}$./100 ml. Liver functiono tests were normal, with total serum proteins $6.13 \mathrm{~g} . / 100 \mathrm{ml}$. (albumin $4.91, \alpha$-globulin $0.49, \quad \beta$-globulin $0.17, \gamma$ 응 globulin 0.56); thymol turbidity less than 1 Maclagan unit; serum alkaline phosphatase 15.2 King-ArmstrongN units $/ 100 \mathrm{ml}$.; serum bilirubin only a trace.

Routine urine examination showed no albumin, bile $\mathbb{N}$ pigments, or myoglobin, and normal microscopy; the స్ట 
24-hour output of creatine was $0.13 \mathrm{~g}$. and of creatinine $0.18 \mathrm{~g}$. Urine chromatography was normal for sugars, showing only glucuronic acid and a trace of glucose and it was normal also for amino-acids, showing small amounts of glycine, alanine, leucine, valine, serine, ethanolamine, threonine, histidine, methyl histidine, glutamic acid, and glutamine.

Special biochemical investigations carried out included an adrenalin tolerance test after intramuscular injection of $0.18 \mathrm{mg}$. adrenalin (Table I), serum enzyme assays as before for aldolase, SGOT, SGPT, and creatine phosphokinase (Table II), and lactic acid production by exercise during ischaemia (Fig. 1). In the latter, though exercise was adequate, and the same techniques used as in the adult patient, fewer specimens were obtained due to difficulties in cooperation.

Studies in vitro were also carried out on biopsy specimens, taken under general anaesthesia, of the patient's left gastrocnemius, soleus, and pectoralis major. On exposure the gastrocnemius looked pale and waxen and felt firm, but the other two muscles seemed normal in appearance and texture. The investigations were performed using exactly the same methods as in the adult patient. The histological appearances are shown in Fig. 3, Fig. 4, and Figs. 6, 7, and 8. The glycogen content is given in Table 1II. Anaerobic glycolysis by a homogenate of pectoralis major is shown in Table IV, and phosphorylase activity of the homogenate in Fig. 2. Again, analysis of glycogen isolated from the biopsy specimens proved its structure to be normal and quite unlike that of phosphorylase limit dextrin or amylopectin.

\section{DISCUSSION}

In the absence of significant neurological signs a diagnosis of myopathy in both patients was supported by the abnormally increased serum activities of aldolase (Thomson, Leyburn, and Walton, 1960; Thomson, 1962) and creatine phosphokinase (Schapira and Dreyfus, 1960; Aebi et al., 1962) found in myopathy but not in neuropathy. Both enzymes are particularly abundant in skeletal muscle, and aldolase, but not creatine phosphokinase, in liver and red cells also.

A diagnosis of muscular dystrophy, however, was considered unlikely. In case 1 the normal electromyogram, the absence of muscular wasting, and a history of full muscular power at rest changing to painful weakness on exercise conformed neither to dystrophy nor to polymyositis. The serum transaminases were scarcely raised compared with their elevations in myopathic wasting (Thomson, 1962); there was no creatinuria, and the E.S.R. was normal. In case 2 a diagnosis of the Duchenne-type muscular dystrophy was possible because of the myopathic electromyogram, the slight general muscular weakness, and the pseudohypertrophy of the calves. However, the muscular weakness was too slight and widespread, the typical pelvic girdle weakness and lordosis were absent, and the serum aldolase and SGPT activities too low for Duchenne-type dystrophy at this age (Thomson, Leyburn, and Walton, 1960; Thomson, 1962). None the less, the elevated SGOT activity and the urinary creatine/creatinine ratio were consistent with myopathic wasting.

These opinions were confirmed at biopsy in both patients. Initial staining of muscle sections with haematoxylin and eosin disclosed no evidence of muscular dystrophy or polymyositis, but instead showed scattered vacuoles in the muscle fibres, so numerous and large in the child's gastrocnemius as to give an appearance like lace-work (Figs. 3 and 4). Since the symptoms of the adult patient, even including the 'second-wind' phenomenon, exactly resembled recent descriptions of a phosphorylasedeficiency myopathy (Schmid and Mahler, 1959; Pearson, Rimer, and Mommaerts, 1961), and since the gastrocnemius biopsy specimen of the child seemed very pale and waxen, frozen sections of all the biopsy specimens were directly stained for glycogen by the periodic acid-Schiff method. The histological appearances (Figs. 5, 6, 7, and 8) then showed, instead of vacuoles, abnormally large amounts of deeply-staining material infiltrating the sarcoplasm and accumulating under the sarcolemma, least marked in the adult gastrocnemius but very gross in that of the child. Formal determination of the glycogen content of all biopsy specimens and of two specimens of normal muscle (Table III) demonstrated conclusively that both patients had skeletal muscle glycogenosis. It is of interest that in the adult the muscle glycogen content was similar to that found in phosphorylase-deficiency myopathy (vide supra). It now remained to define the causal metabolic defect in these clinically dissimilar cases.

Glycogen is the chief storage form of tissue carbohydrate, and is a highly branched polysaccharide of bush-like structure built up from Dglucose units only. These units are joined by $\alpha-1 \rightarrow 4$ linkages in straight chains containing, on the average, about 12 units. Branching occurs through $\alpha-1 \rightarrow 6$ linkages, and in the interior of the molecule the branch points are situated 3 to 4 units apart (Manners, 1957). The molecular periphery has longer chains with scarcely any branching, and is metabolically the most reactive part (Stetten and Stetten, 1955). Glycogen metabolism is directly controlled by at least four enzymes, two for synthesis and two for degradation. Synthesis is by the irreversible action of UDPG-glycogen transferase on UDPG ${ }^{1}$ (Leloir and Cardini, 1957; Villar-Palasi and Larner, 1958) to give $\alpha-1 \rightarrow 4$ linked straight chains, on which amylo$(1,4 \rightarrow 1,6)$-transglucosidase ('branching enzyme') then irreversibly arranges periodic $\alpha-1 \rightarrow 6$ branch ${ }^{1}$ Uridine diphosphate glucose. 


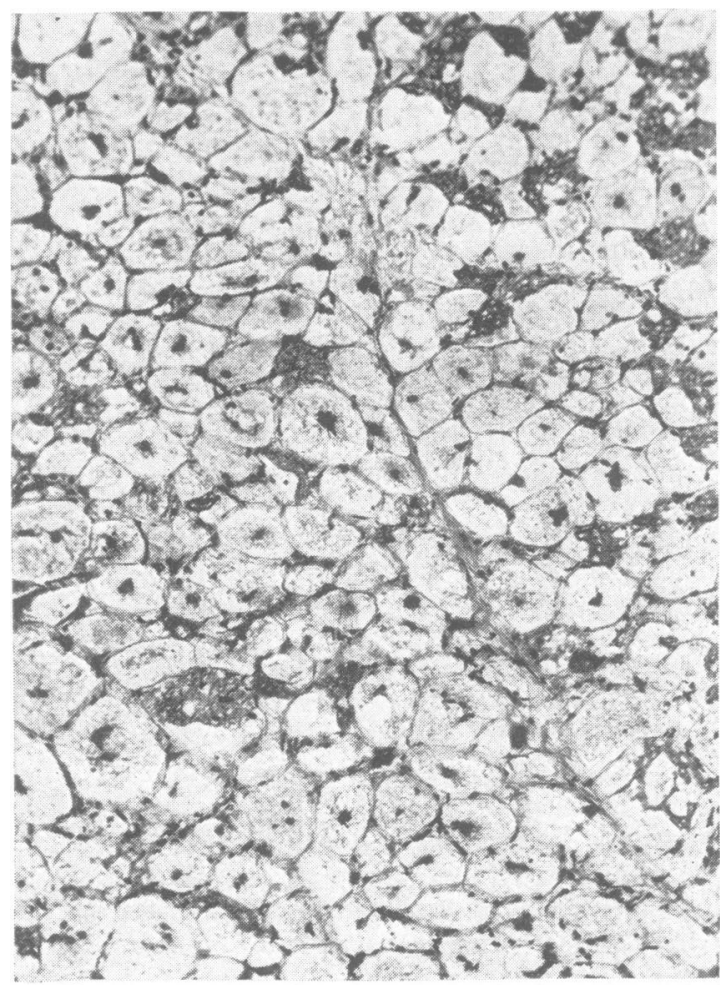

FIG. 3

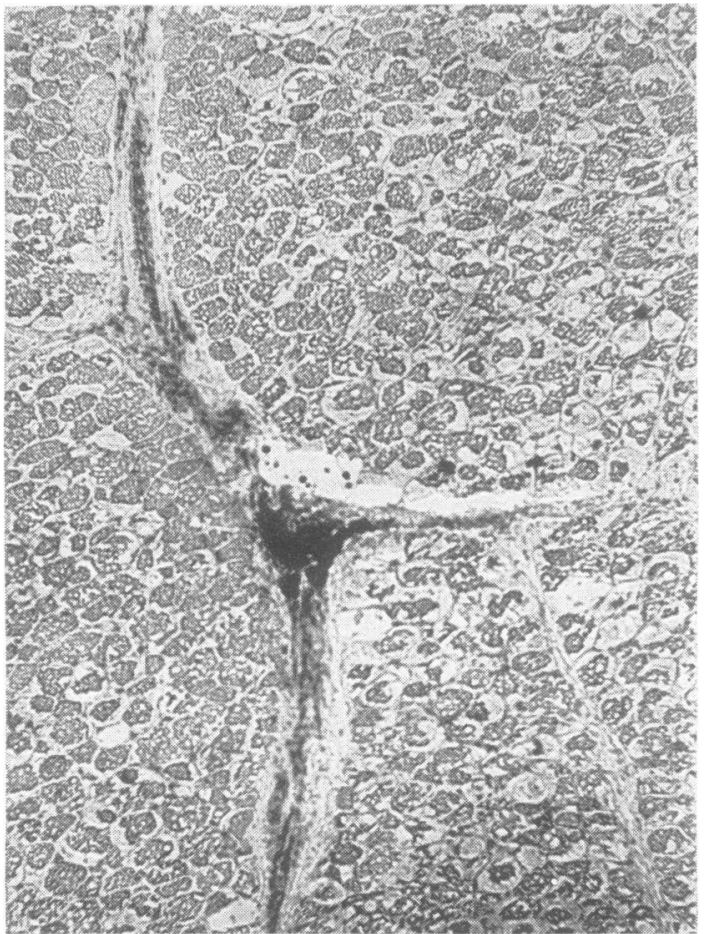

FIG. 4

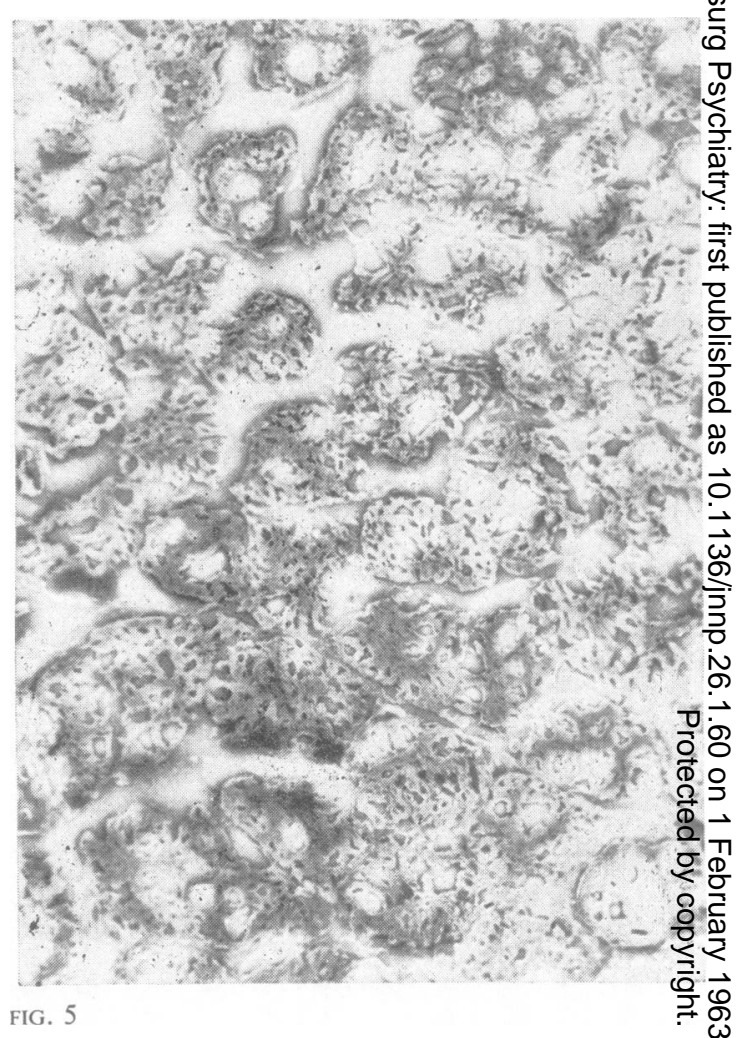

FIG. 3. Case 2 (J.W.). Gastrocnemius $\times 120$ (formols $\mathrm{HgCl}_{2}$, paraffin section, haematoxylin and eosin). The gross lesion is demonstrated. Most muscle fibres have beer replaced, often leaving a nucleus, by a foamy shadow of $\mathbb{D}$ substance eluted during staining and later found to be glycogen.

FIG. 4. Case 2 (J.W.). Gastrocnemius $\times 50$ (formol frozen section, Sudan IV). Some interstitial fat is stained. The unstained areas within the muscle fibres, completely, replacing many of them, represent glycogen eluted duringe staining.

$\underline{3}$

FIG. 5. Case 1 (G.R.). Gastrocnemius $\times 120$ (unfixed frozen section, $P A S)$. The vacuoles in the muscle fibres stain positively for glycogen but there is some freezing artefact and elution of glycogen. 

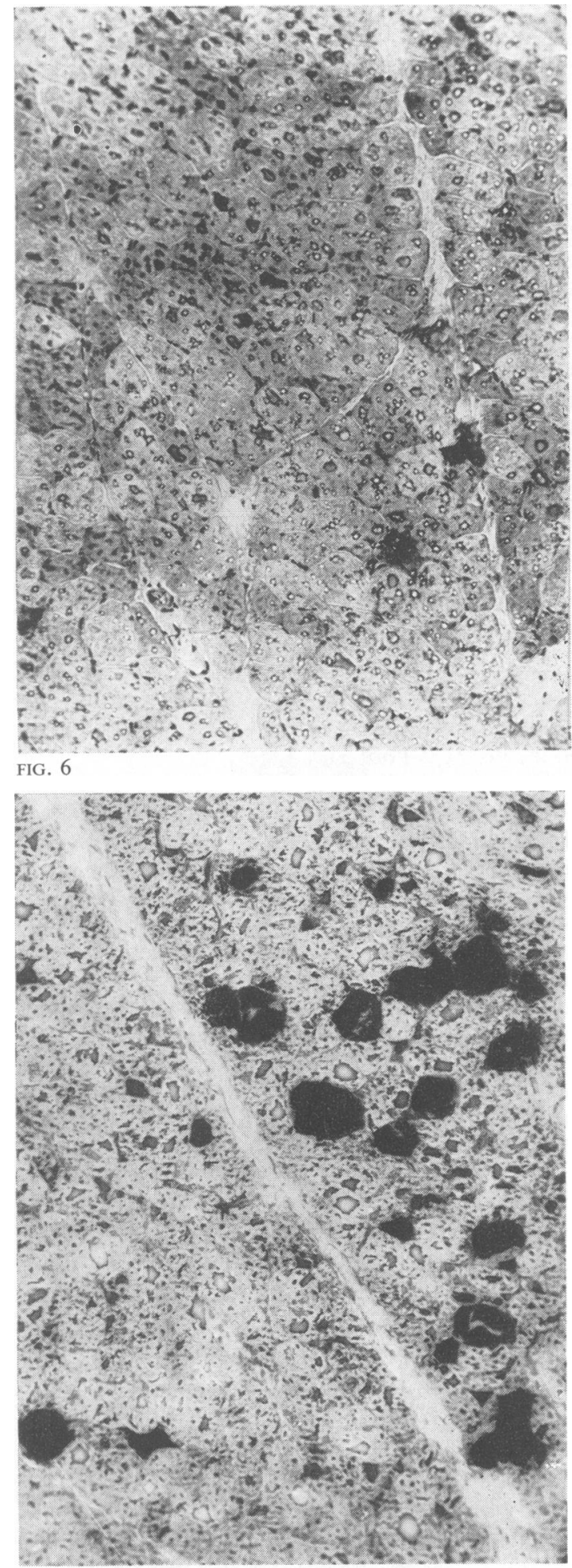

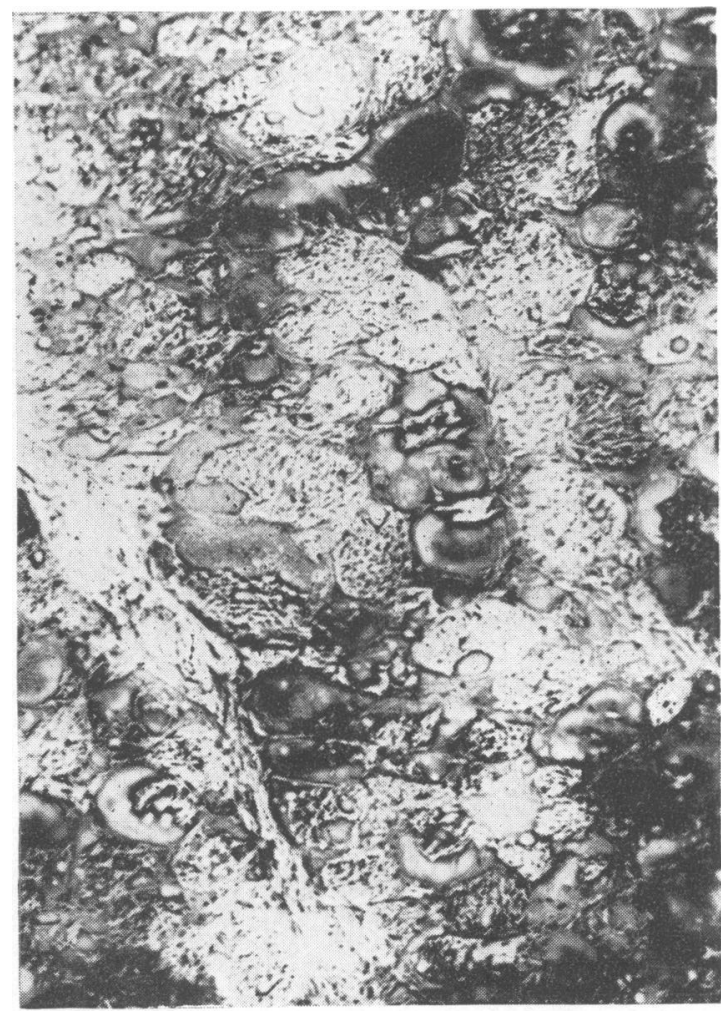

FIG. 8

FIG. 6. Case 2 (J.W.). Pectoralis major $\times 120$ (unfixed, frozen section, $P A S)$. The early lesion is demonstrated, with small amounts of deeply staining glycogen coalescing within the swollen muscle fibres. There is no sarcolemmal reaction and no cellular infiltration.

FIG. 7. Case 2 (J.W.). Soleus $\times 120$ (unfixed, frozen section, $P A S)$. The lesion is more advanced, with deeply staining glycogen in larger masses.

FIG. 8. Case 2 (J.W.). Gastrocnemius $\times 120$ (unfixed, frozen section, $P A S)$. The gross lesion shows severe destruction, with deeply staining glycogen replacing much of the muscle substance.

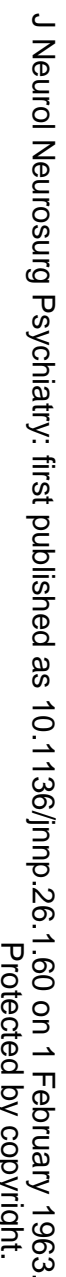

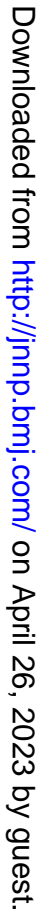




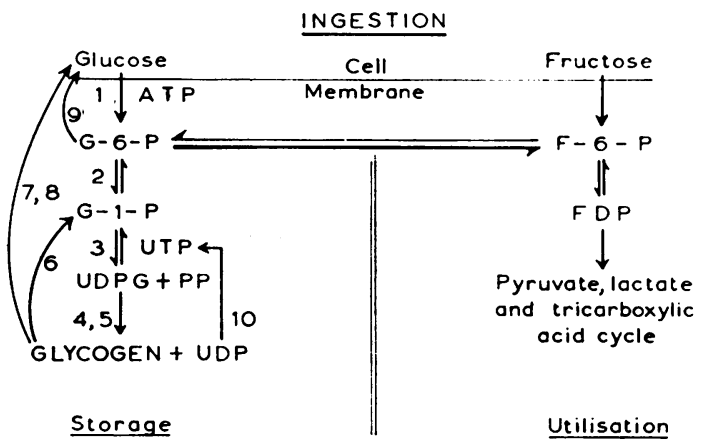

FIG. 9. Diagram of glycogen metabolism. '1Enzyme defects known to cause glycogenosis are marked in the list of abbreviations.

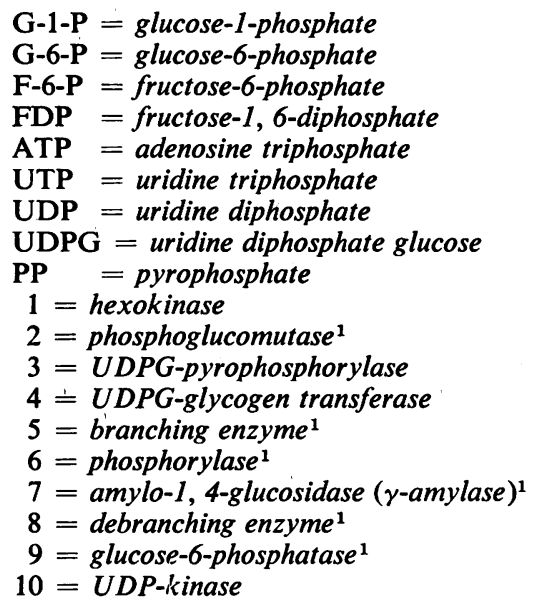

linkages for the growth of additional straight chains. The two enzymes act successively. Degradation is accomplished in the presence of inorganic phosphate by phosphorylase removing single glucose units as G-1-P from the straight chains until stopped by a branch stub, which thus exposed is then removed as free glucose by amylo-1, 6-glucosidase ('debranching enzyme') so that phosphorylase can resume its action. Again, these two enzymes act successively. These reactions initiate the Embden-Meyerhof glycolytic route to the Krebs tricarboxylic cycle, and themselves depend on the integrity of associated enzymecatalysed reactions. Faulty reactions may thus cause imbalance and the abnormal deposition of glycogen in tissues, and Figure 9 illustrates such defects known to cause clinically distinct glycogenoses. The earlier classification by Cori and di Sant'Agnese has been extended by Stetten and Stetten (1960) and is summarized in Table V.

In both patients several types of glycogenosis could be excluded immediately. Normal muscle contains no glucose-6-phosphatase and is not involved in type I; and neither patient showed hepatomegaly, hypoglycaemia, or ketøsis, and both gave the normal hyperglycaemic response to adrenalin (Table I). Likewise, type II could not be considered, since here death occurs within the first year of life from cardiac failure due to generalized glycogenosis with gross cardiac enlargement. The normal structure of the glycogens and the absence of hepatomegaly excluded types III and IV, while type VIa, due to liver phosphorylase defect without muscle pathology, was also excluded by the normal response to adrenalin. Further investigations finally established the nature of the defect in both cases.

During exercise muscle depends chiefly on anaero bic glycolysis for its energy needs since oxyger supply limits aerobic metabolism, and this activg glycolysis is reflected by an increase in lactic aci produced. This is still further increased if the muscle is rendered ischaemic, and the effects of ischaemiz exercise on the blood lactic acid concentrations of both patients and one healthy individual is shown in Figure 1. The normal subject showed the expected steep rise, the child J. W. (case 2 ) only a very slight rise, and the adult G.R. (case 1) none at all. These findings indicated defective muscle glycolysis in both patients, severe in the child and probably total in the adult.

The glycolytic defects were examined by measuring the lactic acid produced on anaerobic glycolysis of various substrates by muscle biopsy homogenates

TABLE V

THE GLYCOGENOSES

\begin{tabular}{|c|c|c|c|c|c|}
\hline Type & Name & Tissues Affected & $\begin{array}{l}\text { Number } \\
\text { Reported }\end{array}$ & Glycogen Structure & Enzyme Defect \\
\hline $\begin{array}{l}\text { I } \\
\text { II }\end{array}$ & $\begin{array}{l}\text { Hepatorenal (von Gierke, 1929) } \\
\text { Cardiac type (Pompe, 1932) }\end{array}$ & $\begin{array}{l}\text { Liver, kidney } \\
\text { Generalized }\end{array}$ & $\begin{array}{r}150 \\
25\end{array}$ & $\begin{array}{l}\text { Normal } \\
\text { Normal }\end{array}$ & $\begin{array}{l}\text { Glucose-6-phosphatase } \\
\text { Probably amylo-1, 4-gluco- } \\
\text { sidase (Hers, 1961) }\end{array}$ \\
\hline III & Limit dextrinosis (Cori, 1956) & Liver, muscle, heart & 16 & Short outer branches & Debranching enzyme \\
\hline IV & Amylopectinosis (Andersen, 1956) & $\begin{array}{l}\text { Liver, reticulo-endothelial } \\
\text { system }\end{array}$ & 1 & Few branch points & Probably branching enzyme \\
\hline $\begin{array}{l}\text { V } \\
\text { VI }\end{array}$ & $\begin{array}{l}\text { Skeletal muscle type } \\
\text { Phosphorylase type }\end{array}$ & Skeletal muscle & 2 & Normal & Several partial defects \\
\hline & $\begin{array}{l}\text { (a) Hepatic (Hers, 1959) } \\
\text { (b) Muscle (Schmid et al., 1959) }\end{array}$ & $\begin{array}{l}\text { Liver } \\
\text { Skeletal muscle }\end{array}$ & $\begin{array}{r}20 \\
4\end{array}$ & $\begin{array}{l}\text { Normal } \\
\text { Normal }\end{array}$ & $\begin{array}{l}\text { Liver phosphorylase } \\
\text { Muscle phosphorylase }\end{array}$ \\
\hline
\end{tabular}


from both patients and one normal individual (Table IV). The defects were confirmed, and in case 2 seemed to involve the glycolytic pathway widely, with special emphasis on phosphoglucomutase and possibly phosphorylase also. In case 1, however, only phosphorylase seemed seriously affected, since glycolysis proceeded satisfactorily through the stages subsequent to it.

Decisive information was obtained by the determination of phosphorylase activity in the muscle biopsy specimens. The results are shown in Fig. 2 compared with those from two specimens of normal muscle. Phosphorylase activity in case 2 was adequate, though rather less than in either normal control; in case 1, however, it was virtually absent.

From the clinical, histological, and biochemical evidence case 1 was clearly one of type VIb glycogenosis due to a complete absence of skeletal muscle phosphorylase. Case 2, on the other hand, was classified as one of type $\mathrm{V}$ glycogenosis with normal muscle phosphorylase activity, but showing more than one enzyme deficiency in subsequent glycolysis, severe in the case of phosphoglucomutase but only partial thereafter. One other case of type V glycogenosis is mentioned by di Sant'Agnese (1959), which seemed clinically similar from the few details then given, except that palatal palsy appears to have been a prominent feature. Muscle glycogen amounted to some $12 \%$ of wet weight, and was found to be structurally normal. Muscle phosphorylase activity was not determined (di Sant'Agnese et al., 1962). Recently two cases have been reported in which multiple enzyme defects elsewhere in glycolysis caused glycogenosis both of liver and skeletal muscle (Abrahamov, Mager, and Shafrir, 1961; Steinitz and Reisner, 1961).

The hydrolytic enzyme amylo-1,4-glucosidase ( $\gamma$-amylase) has now been identified in tissue homogenates (Hers, 1961; Rosenfeld, 1961). This enzyme, operating with the debranching enzyme, degrades glycogen not to G-1-P as does phosphorylase, but to free glucose which, in the presence of intracellular hexokinase and ATP, is converted to G-6-P and enters the glycolytic pathway without the mediation of either phosphorylase or phosphoglucomutase (Fig. 9). This alternative route could explain the 'second-wind' phenomenon on strenuous effort in the adult G.R. (case 1), and the moderate amount of glycogen in his muscle considering the irreversible nature of the UDPG synthetic route and the absence of degradative phosphorylase. Similarly an explanation is found for a sufficient glycolysis in the child J.W. (case 2) despite an apparently severe deficiency of phosphoglucomutase, though adequate still for provision of enough G-1-P for glycogen synthesis by the UDPG system.
The problem of treatment of these patients remained. In the adult G.R. the glycolytic pathway was intact with the sole exception of phosphorylase, and since fructose freely enters this pathway without its mediation and is directly utilized in muscle (Pearson and Rimer, 1959), the patient was given $50 \mathrm{~g}$. fructose in water orally 15 minutes before exertion. This treatment, especially on an empty stomach, produced an extraordinary remission of his symptoms, so that he was able to walk quickly for considerable distances without his usual pain and weakness. Irreversible glycogen synthesis from G-1-P, however, might cause still gre iter accumulation and muscle destruction, so that the safety of this treatment is problematical. Periodic SGOT assay might afford guidance, rising values indicating active destruction and the need for biopsy and estimation of muscle glycogen content. No such logical treatment could be contemplated in the child J.W., due to evidence of a partial glycolytic defect after the stage of FDP, and treatment has been confined to stretchings under anaesthesia of both gastrocnemii to enable him to walk on the flat of his feet. Ho vever, after intermittent support for a year by callipers, now discarded, the child was then able to run about very actively indeed, and since then his clinical condition has remained stationary without evident deterioration.

Besides the two cases of type VIb glycogenosis elucidated by Schmid and Mahler (1959) and by Pearson, Rimer, and Mommaerts (1961), a less typical form has been recorded (Mellick, Mahler, and Hughes, 1962); while a full investigation of the family of the first of these by Schmid and Hammaker (1961) has now disclosed that, though 31 members of the next generation are unaffected, two siblings of the patient showed undoubted signs of the same disorder of skeletal muscle. This indicates autosomal recessive transmission of the condition. While the adult G.R. (case 1) described here gave no family history of a similar complaint, and his four children were all healthy and active, the early death of his only sibling prevented comparable investigation. The child J.W. (case 2) provided no genetic information, since his only sibling was a healthy and symptomless older brother, while both his parents were healthy and neither gave a family history of any similar condition.

\section{SUMMARY}

The procedures are described by which a precise diagnosis was reached in each of two patients, a 48-year-old man and a 4-year-old boy, who exhibited different bizarre disorders of the skeletal musculature.

Systematic studies included assay of the serum 
activities of aldolase, creatine phosphokinase, and glutamic-oxalacetic and glutamic-pyruvic transaminases, the histology of muscle biopsy specimens and their glycogen content and its structure, and the investigation of muscle glycolysis in vivo and finally in vitro, when the nature of the condition was established in each case.

It was demonstrated that the adult patient (case 1) suffered from type VIb glycogenosis due to absence of skeletal muscle phosphorylase, a disorder first described clinically by McArdle (1951). The child (case 2) was diagnosed as a case of type $\mathrm{V}$ glycogenosis with more than one partial glycolytic defect in skeletal muscle, particularly serious in respect of phosphoglucomutase, and is the first case fully to be described and investigated clinically, histologically, and biochemically.

The authors wish to thank Professor J. H. Hutchison, Emeritus Professor Stanley Graham, and Dr. J. H. Wright for permission to publish the findings in these patients, Dr. A. L. Speirs for our introduction to the child J.W., Dr. J. R. Anderson and Dr. A. M. MacDonald for the histology illustrations, Dr. Ian Melville for electromyography, and Dr. David J. Manners and Mr. O. Kjølberg for the determinations of glycogen structure.

\section{REFERENCES}

Abrahamov, A., Mager, J., and Shafrir, E. (1961). Bull. Res. Coun. Israel, E9, 83.

Aebi, U., Richterich, R., Colombo, J. P., and Rossi, E. (1962). Enzymol. biol. clin., 1, 61.

Andersen, D. H. (1956). Lab. Invest., 5, 11.
Beisenherz, G., Boltze, H. J., Bücher, Th., Czok, R., Garbade, K. H., Meyer-Arendt, E., and Pfleiderer, G. (1953). Z. Naturforsch., 8B, 555.

Cho, A. K., Haslett, W. L., and Jenden, D. J. (1960). Biochem. J., 75, 115.

di Sant 'Agnese, P. A. (1959). Ann. N.Y. Acad. Sci., 72, 439.

, Andersen, D. H., and Metcalf, K. M. (1962). J. Pediat., 61, 438.

Good, C. A., Kramer, H., and Somogyi, M. (1933). J. biol. Chem 100, 485.

Gomori, J. (1942). J. Lab. clin. Med., 27, 955.

Hers, H. G. (1959). Rev. int. Hépat., 9, 35.

- (1961). Chem. Weekbl., 57, 437.

Illingworth, B., Cori, G. T., and Cori, C. F. (1956). J. biol. Chem., 218, 123.

Kjølberg, O., and Manners, D. J. (1962). J. chem. Soc., p. 4596

Leloir, L. F., and Cardini, C. E. (1957). J. Amer. chem. Soc., 79, 6340.

McArdle, B. (1951). Clin. Sci., 10, 13.

Manners, D. J. (1957). Advanc. Carbohyd. Chem., 12, 261.

Mellick, R. S., Mahler, R. F., and Hughes, B. P. (1962). Lancet, 1, 1045.

Pearson, C. M., and Rimer, D. G. (1959). Proc. Soc. exp. Biol. (N.Y.), 100,671 .

,$- \frac{10}{502}$, and Mommaerts, W. F. H. M. (1961). Amer. J. Med., 30,

Pompe, J. C. (1932). Nedl. T. Geneesk, 76, 304.

Reitman, S., and Frankel, S. (1957). Amer. J. clin. Path., 28, 56.

Rosenfeld, E. L. (1961). Abstr. Sth int. Congr. Biochem. (Moscow).

Ryan, H. (1958). Analyst, 83, 528.

Schapira, G., and Dreyfus, J.-C. (1960). Europ. Symp. med. Enzymol., 119.

Schmid, R., and Hammaker, L. (1961). New Engl. J. Med., 264, 223. -, and Mahler, R. (1959). J. clin. Invest., 38, 2044.

Slater, E. C. (1953). Biochem. J., 53, 157.

Steinitz, K., and Reisner, S. H. (1961). Bull. Res. Coun Israel, E9p 84.

Stetten, M. R., and Stetten, D., Jnr. (1960). Physiol. Rev., 40, 505. - (1955). J. biol. Chem., 213, 723.

Sutherland, E. W., and Wosilait, W. D. (1956), J. biol. Chem., 218 459.

Thomson, W. H. S. (1962). J. Neurol. Neurosurg., Psychiat., 25, 199

-, Leyburn, P., and Walton, J. N. (1960). Brit. med. J., 2, 1276.

Villar-Palasi, N. C., and Larner, J. (1958). Biochim,. biophys. Act (Amst.), 30, 449.

von Gierke, E. (1929). Beitr. path. Anat., 82, 497. 